\title{
The Formulation Policy on Corporate Criminal Liability System for the 1950 - 2017 Period and its Harmonization in the Renewal of National Criminal Law
}

\author{
Dwidja Priyatno \\ University of Suryakancana,Cianjur and Bandung Law School \\ Email: dwidjapriyatno@yahoo.co.id \\ Kristian \\ Postgraduate Program, University of Suryakancana, Cianjur \\ E-email: yehezkiel.kristian90@gmail.com / kristian@unsur.ac.id
}

How to cite : Priyatno, Dwidja; Kristian, Kristian. (2018). The Formulation Policy on Corporate Criminal Liability Sytem for the 1950-2017 Period and its Harmonization in the Renewal of National Criminal Law . UNIFIKASI : Jurnal Ilmu Hukum, 5(2), 133-143. DOI : 10.25134/unifikasi.v5i2.1392 Submitted : 30-07-2018 Revised : 03-09-2018 Accepted : 09-09-2018

\begin{abstract}
The Criminal Code (KUHP) which currently applies does not recognize corporations as the subject of criminal acts. Therefore, the formulation/legislation policy concerning corporate criminal liability system in Indonesia is only regulated in various specific criminal laws (lex specialis). This research discusses the formulation/legislation policy regarding the corporate criminal liability system in 124 special criminal legislations outside the Criminal Code (KUHP) from 1950-2017. This research used a normative juridical research method as well as interpretation method with a policy-oriented approach. Types and sources of data used were secondary data in the form of primary, secondary, and tertiary legal materials. The collected data were then analyzed based on qualitative analysis method. The results of the research showed that the corporate criminal liability system in legal politics in Indonesia (especially in the formulation/legislation policy) still experiences disorientation and disharmonious. Besides, the national law development should follow every development and/or change of society that is developing in the direction of modernization and globalization and should be able to accommodate all society's needs in various fields. This legal development should be continuously carried out (as a dynamic and an endless process) by "improving (making things better)" and "changing the law to be better and modern".
\end{abstract}

Keywords: Formulation/Legislation Policy, Criminal Accountability System, Corporations, Special Criminal Law.

\section{Kebijakan Formulasi Sistem Pertanggungjawaban Pidana Korporasi Periode Tahun 1950 - 2017 dan Harmonisasinya dalam Rangka Pembaharuan Hukum Pidana Nasional}

\begin{abstract}
Abstrak : Kitab Undang-Undang Hukum Pidana (KUHP) yang saat ini berlaku tidak mengakui korporasi sebagai subjek tindak pidana.Oleh karenanya, kebijakan formulasi/legislasi mengenai sistem pertanggungjawaban pidana korporasi di Indonesia hanya diatur dalam berbagai peraturan perundang-undangan pidana yang bersifat khusus (lex specialis). Penelitian ini akan membahas mengenai kebijakan formulasi/legislasi mengenai sistem pertanggungjawaban pidana korporasi dalam 124 (seratus dua puluh empat) peraturan perundang-undangan pidana khusus di luar Kitab Undang-Undang Hukum Pidana (KUHP) dari tahun 1950-2017. Penelitian ini menggunakan metode penelitian yuridis normatif dan metode interpretasi dengan pendekatan yang berorientasi pada kebijakan (policy oriented approach). Jenis dan sumber data yang dipergunakan adalah data sekunder yang berupa bahan hukum primer, bahan hukum sekunder dan bahan hukum tertier. Data yang telah terkumpul akan dianalisis berdasarkan metode analisis secara kualitatif. Hasil penelitian menunjukan bahwa sistem pertanggungjawaban pidana korporasi dalam politik hukum di Indonesia (khususnya pada kebijakan formulasi/legislasi) masih mengalami disorientasi dan disharmoni. Selain itu, pembangunan hukum nasional harus mengikuti setiap perkembangan dan/atau perubahan masyarakat yang sedang berkembang ke arah modernisasi dan globalisasi serta mampu menampung semua kebutuhan masyarakat di berbagai bidang. Pembangunan hukum seperti ini harus terus-menerus dilakukan (sebagai proses yang dinamis dan proses yang tidak pernah berakhir) dengan cara "menyempurnakan (membuat sesuatu yang lebih baik)" dan "mengubah agar hukum menjadi lebih baik dan modern".
\end{abstract}

Kata Kunci: Kebijakan Formulasi/Legislasi, Sistem Pertanggungjawaban Pidana, Korporasi, Undang-Undang Pidana Khusus. 


\section{INTRODUCTION}

Globalization, modernization and liberalization that occur today, in addition to give positive impact for human life, bring negative side effects such as the existence of "globalization of crime" with increasing quantity and quality (modus operandi) of criminal acts in various fields both within a country and between countries. ${ }^{1}$ Globalization, modernization and liberalization as well as the development of science and technology have also encouraged the growth of new types of crime in the economic, business and financial fields where the impacts resulting from these types of criminal acts are far more dangerous than conventional criminal acts such as robbery, fraud, embezzlement or theft that are common in the society. It is because the new types of crime in the economic, business and financial fields have the potential to undermine the financial system and economy in a country or even the world economic system so that the criminal acts that occur will certainly have an impact on other countries. ${ }^{2}$

The perpetrator or subject of the crime is not only in the form of a natural person (naturlijk person), but it can also be in the form of a "legal entity" (corporation/recht persoon) represented by entrepreneurs who have a high social position and a great financial support. This type of criminal act is no longer carried out with physical violence, such as muggings or robberies, but it is carried out in legitimate business activities. ${ }^{3}$ Therefore, it is worth to say that the new types of crimes in the economic, business and financial fields are said as white collar crimes and the crimes show that economic progress and development have resulted in various new types of crimes that are not less dangerous. This is then known as the "new dimension of crimes".

Today, Indonesia has been hit by contemporary crimes which are sufficiently threatening the environment, energy sources and the new types of crimes in the economic fields such as banking crimes, computer crimes or cyber-crimes, consumer fraud in the form of low quality production which are beautifully

\footnotetext{
${ }^{1}$ Nyoman Serikat Putra Jaya, Globalisasi HAM dan Penegakan Hukum, Makalah disampaikan pada matrikulasi mahasiswa program Magister Ilmu Hukum UNDIP Tahun 2010, pada tanggal 18 September 2010.

${ }^{2}$ Rufinus Hotmaulana Hutauruk, Penanggulangan Kejahatan Korporasi Melalui Pendekatan Restorative Justice Suatu Terobosan Hukum, PT. Sinar Grafika, 2013, pp. 2.

${ }^{3}$ Ibid.
}

packaged and sold through large-scale advertising, and various corporate crimes that operate through penetration and disguise. ${ }^{4}$

Crimes or corporate crimes are ones of the forms of white collar crimes and business crimes with new dimensions of crime as a result of economic and society development which often contain elements of fraud (deceit), misrepresentation, concealment of facts, manipulation, breach of trust, subterfuge or illegal circumvention so that it is very detrimental to the public. ${ }^{5}$

One of the efforts to overcome corporate crimes can be done by making the corporation as a subject of criminal acts where the corporation is deemed to be able to commit criminal acts and can be accountable for criminal acts as well. In this case, the corporation as the subject of criminal acts develops with the rise of crimes or criminal acts committed by the corporation which is supported by the influence of rapid and unavoidable national and international economic and business development.

The review of formulation/legislation policy regarding corporate criminal liability system in criminal law or criminal legislation in Indonesia becomes important because it is included as one of the efforts to overcome crimes by using criminal law facilities, which Marc Ancel calls as "Penal Policy" or Political or Criminal Law Policy. As stated by Marc Ancel, that "penal policy is a science and art, of which practical purposes, ultimately, are to enable the positive rules to be better formulated". 6

However, the regulation of corporate as the subject of criminal acts in the Indonesian criminal law system and national law politics experience some fundamental problems. First, the Criminal Code (KUHP) which is currently in force is a Dutch legacy so that it does not recognize the corporation as the subject of crimes. It is because the Criminal Code (KUHP) still uses the subject of criminal acts in

\footnotetext{
${ }^{4}$ Dwidja Priyatno, Kebijakan Legislasi Tentang Sistem Pertanggungjawaban Pidana Korporasi Di Indonesia, Disertasi, Universitas Katolik Parahyangan (UNPAR), 2003., hlm. 1. Lihat juga dalam: Dwidja Priyatno, Kebijakan Legislasi Tentang Sistem Pertanggungjawaban Pidana Korporasi Di Indonesia, CV. Utomo, 2004., pp. 1.

${ }^{5}$ Romli Atmasasmita, Pengantar Hukum Kejahatan Bisnis, PT. Prenada Media, Jakarta Timur, 2003, pp. xiii.

${ }^{6}$ Barda Nawawi Arief, Beberapa Catatan Terhadap Fenomena Kebijakan Formulasi Hukum Pidana Dalam Berbagai Produk Legislatif di Indonesia, Kuliah Umum di STH Bandung, 11 Okober 2000, pp. 1.
} 
the form of "person" or "natural person" (naturlijk persoon). Second, in practice, there have been often found criminal law formulation/legislation policies, specifically regulating the corporate criminal liability system outside the Criminal Code (KUHP), which contain many problems and/or weaknesses. For example, in the Psychotropic Law, namely Law of the Republic of Indonesia Number 5 of 1997 concerning Psychotropics, the corporate criminal liability system is strictly regulated in the provisions of article 59 paragraph (3) and article 70, while in the Narcotics Act, Law Number 22 of 1997 as amended by Law Number 35 of 2009 concerning Narcotics, the corporate criminal liability system is strictly regulated in the provisions of articles 78 to 82 . In these two laws, there is no provision that explicitly regulates regarding when or in terms of how the corporation is said to have committed a crime and when or in terms of how the corporation can be criminally accountable.

The two laws only regulate who or which party should bear criminal liability. Likewise with its criminal sanctions, the two laws only regulate criminal sanctions for corporations in the form of criminal fines and do not regulate other criminal sanctions when the criminal penalties are not paid by the corporation. In addition, problems are also found in terms of the formulation and definition of "corporation" itself because there are still many specific criminal legislations outside the Criminal Code (KUHP) that formulate "corporations" with various terms, such as "legal entity", "Foundation", "business entity", "everyone", "employer", "company", "union", "organization", "industrial company", "body", "institution", "association", "cooperation", and various other terms.

Formulation/legislation

policy concerning the corporate criminal liability system in various criminal legislations specifically outside the Criminal Code (KUHP) can be said to be inconsistent, disharmonious, overlapping, out of sync or not integrated between one provision and the other. For examples, there are still laws that do not regulate the corporate criminal liability system, there are laws that regulate the corporate criminal liability system with a variety of terms and definitions, there are laws governing the corporate criminal liability system but does not formulate criminal sanctions that can be imposed on corporations, there are laws that regulate the corporate criminal liability system but the formulation of criminal sanctions is formulated singly, and various other problems.

On that basis, this research discusses the formulation/legislation policy regarding the corporate criminal liability system in 124 (one hundred twenty four) special criminal legislations outside the Criminal Code (KUHP) from 1950-2017. Yet, discussing about corporations is very broad. Therefore, the researchers limit this research to examine how the formulation/legislation policy of corporate criminal liability system in various criminal legislations specifically outside the Indonesian Criminal Code in the period of 1950-2017 in the renewal of national criminal law.

\section{METHOD}

Considering that the main focus of this research is on the formulation/legislation policy in determining and/or formulating a corporate criminal liability system in criminal law, this research is conducted through normative juridical research method. The data used in this research is emphasized on secondary data, including; 1) primary legal materials, namely binding legal materials consisting of basic regulations (the 1945 Constitution of the Republic of Indonesia and its amendments) and legislations concerning the topic of the research; 2) secondary legal materials, namely legal materials that provide further explanation regarding primary legal materials in the form of books, journals, Supreme Court regulations, materials for seminars and symposiums, academic texts, results of panel discussions, research results, draft of laws, and some literature relating to research topic; and 3) tertiary legal materials, namely legal materials that provide guidance and explanation of primary and secondary legal materials, including Indonesian Dictionary, encyclopedia, legal dictionary, and other related materials. ${ }^{7}$ The data collection is carried out through documentation and literature studies, while the data analysis methods applied in this research are qualitative and descriptive.

\section{RESULTS AND DISCUSSION}

\footnotetext{
${ }^{7}$ Soerjono Soekanto dan Sri Mamudji, Penelitian Hukum Normatif Suatu Tinjauan Singkat, Jakarta, CV. Rajawali, 1985, pp. 14-15.
} 
Article 1 Point 3 of the 1945 Constitution of the Republic of Indonesia as the State constitution states that Indonesia is a state of law (Rechtstaat). The main objective of the state of law is to organize orderliness. ${ }^{8}$ The term "corporation" is a term commonly used by criminal and criminology law experts to refer to what in other areas of law, especially the civil law referred to as "legal entities", or in Dutch it is called "recht person" or in English it is called "legal person" or "legal body". 9 Corporate crime is a form of crime or criminal act classified as new, and through various legislations, corporation has been accepted as a legal subject and treated the same as the natural law subject of man. ${ }^{10}$ Formulation/legislation policy concerning the corporate criminal liability system is regulated in various special legislations outside the Criminal Code (KUHP) which now consists of 124 (one hundred twenty four) laws. The 124 laws can be grouped into 3 periods, namely the $1950-1980$ period (there are at least 20 laws), the 1990-2000 period (there are at least 35 laws), and the 2001-2017 period (there are at least 69 laws).

The results of the research show that the formulation/legislation policy regarding the corporate criminal liability system in Indonesia is only regulated in various special criminal legislations (lex specialis). The current corporate criminal liability system is not recognized in general criminal law (lex generali) or is not explicitly regulated in the Criminal Code (KUHP). This is because the current Criminal Code (KUHP of the Dutch Legacy) still regulates the subject of criminal acts in the form of "person" or "human" in natural biological connotations, so that the legal subject in the KUHP is only a natural person (natuurlijke persoon). It is because the compilers of the Criminal Code (KUHP) accept the principle of "Societas Delinquere Non Potest" or "Delinquere Non Potest University" which states that a legal entity (corporation) cannot commit a crime and, as a consequence, it cannot be asked for criminal liability. The same thing can be seen in the memorie van

\footnotetext{
${ }^{8}$ Ahmad Hunaeny dan Tanti Kirana Utami, Perlindungan Hukum terhadap Pekerja dalam Pelaksanaan Hubungan Industrial, PJIH Volume 3 Nomor 2 Tahun 2016, FH-UNPAD, Bandung, pp. 407

"Sekhroni, Penerapan Asas "Premium Remedium" Terhadap Pertanggungjawaban Pidana Korporasi Industri Pertambangan Di Indonesia, Jurnal Unifikasi, ISSN 2354-5976 Vol. 04 Nomor 01 Januari 2017, pp. 15

${ }^{10}$ Burhanudin, Tindak Pidana Korupsi Sebagai Kejahatan Korporasi, Jurnal Cita Hukum, Vol. I No. 1 Juni 2013, pp. 76.
}

toelichting (MvT) of the Criminal Code (KUHP) which was valid on 1 September 1886 stating that: "A criminal act can only be done by an individual (natuurlijke persoon)".

As stated previously, the corporate criminal liability system in Indonesia is only regulated in various special legislations (lex specialis). In the 1950-1980s periods, the corporate criminal liability system had begun to be regulated in various legislations. In this period, there were at least twenty laws. However, the corporate arrangement as the subject of criminal acts in this period still uses various terms, for example: "Legal Entity", "Employer", "Company", "Trustee", "Foundation", "Organization", "Business Entity", "Industrial Company", and other various terms (the terms "Legal Entity" is commonly used). Thus, in this period, the formulation of the term "corporation" was not yet known and had not been used explicitly.

Although the corporation (which is formulated by the term "legal entity" and other terms) has been recognized as the subject of criminal acts, the majority of criminal liability in this period is charged to the management or organ as a representative or party that carries out the legal entity's management (from 20 laws, 15 laws in this period stated so). Nevertheless, it should be noted that in this period, the Law of the Republic of Indonesia Number 17 of 1951 concerning the Stockpiling of Goods had strictly regulated that the corporation or its management or corporation and its management could be charged with criminal liability (direct liability from the corporation has been already set up). It is formulated in the provisions of article 11 paragraph (1) which states: "if an act that is allowed to be punished under this law, is carried out by a legal entity, then the claim is made and the sentence imposed on the legal entity or on the intended people in paragraph (2) (carried out by a person or more who can be considered acting individually or jointly committing a crime in the name of a legal entity) or against both of them" (bold and italic made by the researchers).

The concepts and theories of corporate liability in civil law cannot be equated with corporate liability in criminal law. ${ }^{11}$ It needs to

\footnotetext{
${ }^{11}$ Mardjono Reksodipuro, Kejahatan Korporasi Suatu Fenomena Lama Dalam Bentuk Baru, Indonesian Journal Of International Law, 1 Volume / Nomor 4Juli 2004, pp. 699.
} 
be noted that the formulation/legislation policy regarding the corporate criminal liability system in the Republic of Indonesia Law Number 7 of 1955 concerning Investigation, Prosecution and Economic Criminal Justice or what is known as the "economic crime" law has been formulated comprehensively. Therefore, this law is often used as a reference or model in regulating the corporate criminal liability system. It is because the law has completely formulated or regulated the outlines or common threads relating to the corporate criminal liability system [in this law, the corporation has been regulated as the subject of criminal acts (although it is formulated by the terms "legal entity, company, union or foundation"), the party that must bear criminal liability (the corporation and/or its management), the qualification of the act as a corporate criminal act and the criminal sanction threatened].

During this period, there were still many laws that had not been strictly and clearly regulated the qualification of acts as corporate crimes. The qualification of the acts in question is in what case criminal acts or crimes committed by a person or natural person as an organ or management of a corporation can be categorized as criminal acts committed by the corporation and therefore, the corporation is worthy of criminal liability (out of 20 laws under study, only 5 laws regulate it). Regarding the type of sanctions (criminal sanctions) that are threatened, most of the laws in this period have not clearly defined criminal sanctions for corporations (many of the laws do not regulate or regulate criminal sanctions in the form of imprisonment which cannot immediately be applied to corporations and there are also several laws that regulate criminal fines or seizure of goods).

Until the birth of the Republic of Indonesia Emergency Law Number 7 of 1955 concerning Investigation, Prosecution and Economic Criminal Acts (in which its pattern was followed by the Republic of Indonesia Emergency Law Number 11 PNPS in 1963 concerning Subversion Crimes), ${ }^{12}$ criminal sanctions for corporations began to be formulated comprehensively that is by regulating the basic criminal, additional criminal and disciplinary or temporary actions that can be imposed on corporations

12 Undang-Undang ini sudah dicabut dan dinyatakan tidak berlaku. committing criminal acts (many laws thereafter do not adopt the pattern in the Emergency Law of the Republic of Indonesia Number 7 of 1955 so that the formulation/legislation policy regarding the corporate criminal liability system becomes unclear).

In researchers' point of view, the formulation/legislation policy of the corporate criminal liability system in the period 19501980 was still dominated by the old thought which states that corporations (legal entities) cannot commit criminal acts and certainly cannot account for criminal acts. In this period, the criminal responsibility system adopted is "the administrator as the actors of criminal acts so that the administrator should account for his criminal acts" or the stage I corporate criminal liability system. Thus, those who can commit criminal acts and are criminally accountable are only natural people. Nevertheless, it cannot be denied that some of the existing laws in this period have been in stage II where corporations are considered to be able to commit criminal acts but their criminal liability is charged to the management or organ of the related corporation. This period can be regarded as the initial transition period to the stage III corporate criminal liability system where the corporation is considered to be able to commit criminal acts and account for criminal acts as well (because in the Emergency Law of the Republic of Indonesia Number 7 of 1955 concerning Criminal Investigation, Prosecution and Economic Criminal Acts, the Emergency Law of the Republic of Indonesia Number 11 PNPS in 1963 Concerning Subversion, and the Emergency Law of Republic of Indonesia Number 17 of 1951 concerning Stockpiling of Goods, the corporation has been directly accountable).

In the period 1990-2000, the formulation/legislation policy regarding the corporate criminal liability system received more attention from legislators. It is proved by the increasing number of special laws (lex specialis) which regulate the corporate criminal liability system. However, similar to the previous period, the corporate arrangement as the subject of criminal acts in this period was still formulated by using various terms, for example, "Legal Entity", "Business Entity", "Entrepreneur", "Agency", "Company", "Institution" , "Association", "Foundation", "Cooperation", "Organization", and other various terms, even there are still laws that 
formulate the term "Every Party". However, it should be realized that in this period, the term "corporation" was introduced in the legal domain (especially criminal law) in Indonesia. It is strictly regulated for the first time in the Law of the Republic of Indonesia Number 5 of 1997 concerning Psychotropic which is then followed by the Law of the Republic of Indonesia Number 22 of 1997 as amended by Law of the Republic of Indonesia Number 35 of 2009 concerning Narcotics, and Law of the Republic of Indonesia Number 31 of 1999 as amended by Law of the Republic of Indonesia Number 20 of 2001 concerning Eradication of Criminal Acts of Corruption (although it is very unfortunate that after the enactment of the Law of the Republic of Indonesia Number 5 of 1997 concerning Psychotropic, many laws thereafter returned to use various terminologies to describe "corporation").

In this period, half of the laws under study (19 of the 35 laws existing in this period) had not explicitly regulated those who had to be responsible for their crimes when corporate criminal acts occurred. Meanwhile, the laws in this period that have firmly regulated those who have to be responsible for criminal acts when corporate criminal acts occurred are only 16 laws. In this period, the unclear qualification of a criminal act as a corporate criminal act (when and in terms of how a criminal act or a crime committed by the management/organ can be said or qualified or categorized as a corporate crime) will cause serious problems. It is because in this period, most of the laws ( 29 of 35 laws) have not clearly and definitively regulated the qualification of a criminal act as a corporate crime so that the corporation is eligible for criminal liability.

Furthermore, with regard to criminal sanctions for corporations, in this period, criminal sanctions for corporations tend to be equated with criminal sanctions for natural people or individuals [there are even laws that do not regulate them explicitly (there are at least 2 laws)]. In general, the criminal sanctions threatened against perpetrators of criminal acts (including corporations) are in the form of imprisonment and fines (there are at least 25 of the 35 laws existing in this period). Nevertheless, it should be noted that there began to be a law that specifically regulates criminal imposition of corporations in this period.
Criminal penalties for corporations are carried out by imposing penalties with weighting (for examples, the criminal penalty is added $1 / 3$, criminal fines are 2 times of criminal penalties that apply to the crime, and so on). There are also additional penalties (in the form of revocation of business licenses and/or dissolution of corporations, compensation, announcement of judges' decisions, and other criminal sanctions) that can be imposed on corporations as well as disciplinary actions (seizure of profits, reparation of criminal acts, obliging to do what is neglected without rights, and so forth) to corporations that commit criminal acts and administrative sanctions (for examples, in the form of administrative fines, revocation of business licenses, suspension or limitation of business activities, etc.). Some of the laws regulating the penalties are the followings: Law of the Republic of Indonesia Number 8 of 1992 concerning Film, Law of the Republic of Indonesia Number 10 of 1995 concerning Customs, Law of the Republic of Indonesia Number 11 of 1995 concerning Excise, Law of the Republic of Indonesia Number 5 of 1997 concerning Psychotropic, Law of the Republic of Indonesia Number 22 of 1997 concerning Narcotics, Law of the Republic of Indonesia Number 23 of 1997 concerning Environmental Management, Law of the Republic of Indonesia Number 8 of 1999 concerning Consumer Protection, Law of the Republic of Indonesia Number 20 of 2001 concerning Eradication of Corruption, etc.

In researchers' point of view, the corporate criminal liability system as contained in various existing laws in this period is still in stage II, where corporations are considered to be able to commit criminal acts but criminal liability is charged to the management or their organs or at least this period is the transitional period of criminal liability stage II corporation (where the corporation is considered to be able to commit a criminal act but criminal liability is charged to the management or its organ) to the stage III corporate criminal liability system where the corporation and/or its management can be directly responsible for criminal liability.

Furthermore, the formulation/legislation policy concerning the corporate criminal liability system in the period 2001-2017 was slightly more advanced and more comprehensive compared to the two previous periods. It is because in this period, 
the formulation/legislation policy concerning the corporate criminal liability system has been more consistently regulated by using the term "Corporation" and this has been clearly regulated (there are 32 laws from 69 laws examined). However, it cannot be denied that in this period there were still several laws that used other terms, such as "Agency", "Legal Entity", "Foundation", "Business Entity", "Company", "Association" and etc.

With regard to legal subjects or parties who have to bear criminal liability, in this period, it can be grouped into 3 major parts, namely: the laws that do not formulate who or which party should bear criminal liability, the laws that regulate criminal liability is only charged to the management or its organs (natural people/individual), and the laws which explicitly regulate that the corporation and/or its management are parties who should bear criminal liability. The three groups are as follows:

1) The laws that do not formulate or do not regulate which party should bear criminal liability: there are at least 24 laws out of 69 laws.

2) The laws regulating that criminal liability is only charged to the management or its organs (natural people): there are at least 9 laws out of 69 laws.

3) The laws which explicitly regulate that the corporations and/or their administrators are parties who should bear criminal liability: there are at least 35 laws out of 69 laws.

Note: 1 law, namely the Law of the Republic of Indonesia Number 1 of 2012 Concerning the Ratification of the Comprehensive Nuclear Test Ban Treaty and the Treaty does not explicitly regulate the parties who have to bear the responsibility.

During this period, many laws did not clearly and explicitly regulate the qualifications or categorization of acts as corporate crimes (when and in terms of how crimes committed by organs or management can be said or qualified or categorized as corporate crimes) and therefore, the corporation deserves to be liable for criminal liability. The results of this research show that of the 69 laws under study, only 15 laws have explicitly regulated qualifications or categorization of acts as corporate criminal acts. On the contrary, 54 laws have not formulated them firmly. This qualification or categorization of acts as corporate criminal acts certainly needs serious attention from the legislators because it will greatly affect the application and execution of the corporate criminal liability system in law practice and law enforcement process in Indonesia.

In this period, criminal sanctions threatened against corporations committing crimes were regulated more comprehensively. The principal crimes that can be imposed on corporations are generally criminal fines and criminal fines with weighting. During this period, there have been various alternative criminal sanctions that could be imposed on corporations, such as the announcement of a judge's decision, suspension of part or all business activities of the corporation, revocation of business licenses, seizure of assets resulting from criminal acts, repairs due to crime, dissolution and/or prohibition of corporations, deprivation of corporate assets for the state, corporate takeover by the state, criminal weighting for corporations, termination of assistance/grants and other sanctions (as an additional criminal or disciplinary action). It should be noted that in this period, there were also many laws regulating administrative sanctions for corporations. Nevertheless, it cannot be denied that there were still laws that did not regulate criminal sanctions for corporations firmly and clearly.

In addition, in this period, there were several legislations that firmly formulated alternative criminal sanctions for corporations that did not carry out the criminal penalties imposed on them. These legislations are Law of the Republic of Indonesia Number 08 of 2010 concerning Prevention and Eradication of Money Laundering, Law of the Republic of Indonesia Number 7 of 2011 concerning Currency, Law of the Republic of Indonesia Number 9 of 2013 concerning Prevention and Eradication of Criminal Financing of Terrorism, Regulation of the Supreme Court of the Republic of Indonesia Number 13 of 2016 Concerning Procedures for Handling Criminal Cases by Corporations, and the Draft of National Criminal Code of July 2018 version. These legislations essentially state: "In the case of The corporation is unable to pay criminal penalties, the fine is replaced with the seizure of assets belonging to the Corporation or Corporate Control Personnel in which its value is the same as the criminal penalty imposed on 
them, and so on ... ". In researchers' point of view, the corporate criminal liability system in this period has basically entered the stage III liability system where the corporation and/or its administrators are considered capable of committing criminal acts and criminal liability can also be imposed on them.

Complementing various weaknesses related to the formulation/legislation policy of the corporate criminal liability system in various special criminal laws spread outside the Criminal Code (KUHP) as previously described, the Regulation of the Supreme Court of the Republic of Indonesia Number 13 of 2016 concerning Procedures for Handling Criminal Cases by Corporations was issued in 2016. In its consideration, it was explicitly stated that many laws in Indonesia have placed corporations as the subject of criminal acts that can bear criminal liability, but cases with corporate subjects submitted to the court are still very limited. One of the causes is the procedures for corporate inspection as a criminal perpetrator is still unclear. Therefore, it is necessary to have guidelines for law enforcement officers in handling criminal cases committed by corporations.

Likewise, Article 2 of the Supreme Court Regulation states that the purposes of establishing the procedure for handling criminal cases by the Corporation are to:

1. Be a guideline for law enforcement officers in handling criminal cases committed by Corporate and/or its Management;

2. Fill in the legal vacuum, especially criminal procedural law in handling criminal cases committed by Corporate and/or its Management; and

3. Encourage the effectiveness and optimization of criminal cases handling committed by Corporate and/or its Management.

In the most recent developments, the corporate criminal liability system has begun to enter stage IV (four), namely the regulation of the corporate criminal liability system in general criminal law (lex generalis). It is stated in the Book I of the National Criminal Code (KUHP) in which the corporate criminal liability system can be applied to all types of criminal acts [until this paper is written, the general criminal law is still a draft (Draft Penal Code of July 2018 version)].

Djuhaendah Hasan in his book entitled "Lembaga Jaminan Kebendaan Bagi Tanah dan Benda Lain yang Melekat Pada Tanah dalam Konsepsi Penerapan Asas Pemisahan Horizontal", quoting the opinion of Sunaryati Hartono, states that the development of national law should be able to follow the development of society that is developing towards modernization. Moreover, legal development should be able to accommodate all society's needs in all fields. Legal development includes efforts to improve (make things better), to change to become better and more modern, to do something that previously did not exist, or to eliminate something contained in the old system because it is not needed and no longer matches the new system. ${ }^{13}$ Legal development should cover the above matters so that legal development becomes a dynamic process that should be carried out continuously and even a never ending process because every progress will demand changes in a society that is constantly changing. ${ }^{14}$ It is in line with what was stated by Henny Nuraeny \& Tanti Kirana Utami in their writings entitled The Victim Handling Model of Human Trafficking that "then one as the deciding factor in holding power is the norm or law". ${ }^{15}$

Therefore, the process of reorienting and reformulating the corporate criminal liability system in Indonesian legislations in the context of renewal of national law, the legislators should pay attention to several things, as follows:

a. Definition of Corporation.

In formulating the corporate criminal liability system in the future, it should be regulated consistently and firmly by using the term "corporation". Then, a corporation in criminal law context should be interpreted as a group of organized people and/or assets that are both legal and nonlegal entities.

b. Legal subjects or parties who should bear criminal liability.

In formulating the corporate criminal liability system in the future, it should be clearly regulated that the party which bears criminal liability is "Corporation and/or its

\footnotetext{
${ }^{13}$ Djuhaendah Hasan, Lembaga Jaminan Kebendaan Bagi Tanah dan Benda Lain yang Melekat Pada Tanah dalam Konsepsi Penerapan Asas Pemisahan Horizontal, Citra Aditya Bakti, Bandung, 1996, pp. 3.

${ }^{14}$ Ibid.

${ }^{15}$ Henny Nuraeny \& Tanti Kirana Utami, The Victim Handling Model of Human Trafficking through Economic Independence, Vol. 16 No. 2 Mei 2016, FH-UNSOED, pp. 121. DOI. 10.20884/1.jdh.2016.16.2.507.
} 
Management". Thus, criminal liability can be imposed on the management, on the corporation or on both the corporation and its management.

c. Classification/categorization of actions as corporate crimes.

In formulating the corporate criminal liability system, it is also necessary to be explicitly regulated in national legislation concerning the classification or categorization of acts as criminal acts committed by corporations (when and in terms of how a criminal act committed by a management or organ can be said or categorized as a corporate crime). The classification of criminal acts that can be categorized as corporate crimes includes: a criminal act committed by corporate control personnel (as senior officers or directing mind); a criminal act carried out because it is legally ordered by corporate control personnel (the delegation by the legal party); a criminal act carried out by an agent or organ or management on behalf of the corporation or carried out within the scope of its work; a criminal act carried out in order to achieve corporate's purposes and objectives; a criminal act carried out by agents that are closely related to the corporation; a criminal act carried out in accordance with the duties and functions of the perpetrator or the person giving orders; a criminal act carried out based on a decision from a group of people in the related corporation; the corporation does not establish a system, procedure, internal discipline or supervision and culture in a corporation that can prevent and take action against criminal acts; the corporation fails to take action against the violations of law that occur in the corporation, and a criminal act carried out with a view to providing benefits or profits for the corporation.

d. Types of Criminal Sanctions against Corporations.

It is necessary to regulate alternative criminal sanctions (either as a basic sanction or as an additional sanction or as a disciplinary action) that can be imposed on a corporation that is legally and convincingly proven to commit a criminal act. The alternative criminal sanctions include: criminal fines, revocation of certain rights, deprivation of property or assets belonging to the corporation, publicity sanctions for example the announcement of a judge's decision or the inclusion of a company (corporation) in the company's black list, seizure of profits, corporate supervision, recovery due to criminal acts , compensation, restitution and compensation to victims, substitution of economic benefits, community service, limitation of activities or business activities of the corporation, prohibition of advertising on goods and/or services, cancellation of licenses, takeover of corporations by the state, recovery of state losses, if sanctions are not cause a deterrent effect, with all considerations, the corporation can be closed (should be done with caution because it can have an impact on other parties who are innocent and can be a criminal factor).

The process of reorienting and reformulating of the corporate criminal liability system in various legislations in relation to the handling of corporate criminal acts and the renewal of national criminal law is in line with the understanding of strafrechtspolitiek as stated by A. Mulder and Marc Ancel. A. Mulder that the crime prevention policy using criminal law or penal policy is a policy line to determine how far the applicable criminal provisions need to be changed or renewed (in welk opzicht de bestaande strafbepalingen herzien dienen te worden). ${ }^{16}$ Likewise, Marc Ancel states that a "penal policy" or criminal law policy is "a science and art, of which the practical purposes, ultimately, are to enable the positive rules to be better formulated". ${ }^{17}$

\section{CONCLUSION}

Article 1 Point 3 of the 1945 Constitution of the Republic of Indonesia as the State constitution declares that Indonesia is a state of law (Rechtstaat). The main objective of the state of law is to organize orderliness in order to achieve the protection and welfare of the society. However, these objectives will not be achieved when there are criminal acts. In the current era of globalization, modernization and liberalization, the Indonesian nation is being hit by contemporary crimes which are quite threatening where the perpetrators of these crimes are not only in the form of natural

\footnotetext{
${ }^{16}$ Soedarto, Kapita Selekta Hukum Pidana, PT. Alumni, Bandung, 2006, pp. 332.

${ }^{17}$ Barda Nawawi Arief, Beberapa Catatan ...,Op.Cit., pp. 1.
} 
person (naturlijk person) but also in the form of corporations.

The formulation/legislation policy concerning the corporate criminal liability system in Indonesia is only regulated in various special criminal legislations (lex specialis) spread in 124 (one hundred and twenty four) laws which can be grouped into 3 (three) periods, namely the period 1950-1980s (there were at least 20 laws), the period 1990-2000 (there were at least 35 laws), and the period 2001-2017 (there were at least 69 laws). From various laws regulating the corporate criminal liability system, corporate regulation as the subject of criminal acts in the Indonesian criminal law system experiences some fundamental problems. Formulation/legislation policy concerning the corporate criminal liability system (especially concerning the definition of corporation, parties that should bear criminal liability, classification/categorization of acts as corporate criminal acts, and types of criminal sanctions against corporations) in various special criminal laws outside the Criminal Code (KUHP) can be said to be disorientation, inconsistent, disharmonious, overlapping, out of sync or not integrated between one provision and the other.

On that basis, it is necessary to reorient and reformulate the corporate criminal liability system in Indonesia in order to overcome corporate crimes and the renewal of national criminal law because law should follow every development of society and the development of the times that are developing towards modernization. The reorientation and reformulation are also in accordance with the understanding of crime prevention policy by using penal law as stated by A. Mulder and Marc Ancel that criminal law policy is a policy line to determine how far the applicable criminal provisions need to be changed or renewed so that a better positive law is established.

\section{SUGGESTION}

By paying attention to the weaknesses in the formulation/legislation policy relating to the corporate criminal liability system in 124 (one hundred twenty four) special criminal legislations spread outside the Criminal Code (KUHP), in order to overcome corporate criminal acts and national criminal law reform (penal reform), it is necessary to reorient and reformulate concerning the definition of corporation, the party that should bear criminal liability, classification/categorization of actions as corporate criminal acts, and the type of criminal sanctions against a corporation committing a criminal act.

\section{REFERENCES}

\section{A. Books}

Barda Nawawi Arief. (2000). Beberapa Kebijakan Formulasi Hukum Pidana Dalam Berbagai Produk Legislatif di Indonesia, Kuliah Umum di STH Bandung, 11 Okober 2000.

Djuhaendah Hasan. (1996) Lembaga Jaminan Kebendaan Bagi Tanah dan Benda Lain yang Melekat Pada Tanah dalam Konsepsi Penerapan Asas Pemisahan Horizontal, Citra Aditya Bakti, Bandung.

Dwidja Priyatno. (2003), Kebijakan Legislasi Tentang Sistem Pertanggungjawaban Pidana Korporasi Di Indonesia, Disertasi, Universitas Katolik Parahyangan (UNPAR), 2003.

Dwidja Priyatno. (2003). Kebijakan Legislasi Tentang Sistem Pertanggungjawaban Pidana Korporasi Di Indonesia, CV. Utomo, 2004.

Nyoman Serikat Putra Jaya (2010). Globalisasi HAM dan Penegakan Hukum, Makalah disampaikan pada matrikulasi mahasiswa program Magister Ilmu Hukum UNDIP Tahun 2010, pada tanggal 18 September 2010.

Romli Atmasasmita, Pengantar Hukum Kejahatan Bisnis, PT. Prenada Media, Jakarta Timur, 2003.

Rufinus Hotmaulana Hutauruk. (2013). Penanggulangan Kejahatan Korporasi Melalui Pendekatan Restorative Justice Suatu Terobosan Hukum, PT. Sinar Grafika.

Soedarto (2006). Kapita Selekta Hukum Pidana, PT. Alumni, Bandung.

Soerjono Soekanto dan Sri Mamudji (1985). Penelitian Hukum Normatif Suatu Tinjauan Singkat, Jakarta, CV. Rajawali.

\section{B. Journals}

Ahmad Hunaeny Zulkarnaen dan Tanti Kirana Utami (2016). Perlindungan Hukum 
terhadap Pekerja dalam Pelaksanaan Hubungan Industrial, PJIH. 3(2).

Burhanudin. (2013) Tindak Pidana Korupsi Sebagai Kejahatan Korporasi, Jurnal Cita Hukum, Vol. I No. 1 Juni 2013.

Henny Nuraeny \& Tanti Kirana Utami. (2016) The Victim Handling Model of Human Trafficking through Economic Independence, Vol. 16 No. 2 Mei 2016, FH-UNSOED, DOI 10.20884/1.jdh.2016.16.2.507.

Mardjono Reksodipuro. (2004) Kejahatan Korporasi Suatu Fenomena Lama Dalam Bentuk Baru, Indonesian Journal Of International Law, 1 (4).

Sekhroni. S. (2017). Penerapan Asas "Premium Remedium" Terhadap Pertanggung Jawaban Pidana Korporasi Industri Pertambangan di Indonesia, UNIFIKASI : Jurnal Ilmu Hukum. 4 (1). 